ISSN : 2746-7155 (Online), ISSN : 1978-4996 (Print)

MAKILA:Jurnal Penelitian Kehutanan Volume 13, Nomor 2 (139-149)

DOI : http:/ / doi.org/ 10.30598/makila.v13i2.2440

®2019 Jurusan Kehutanan UNPATTI

\title{
Hak Tenurial Masyarakat Adat Dalam Pengelolaan Hutan
}

\author{
(Tenure Rights of Indigenous Peoples in Forest Management) \\ Haryanto Ririn V. $1^{*}$, Marthina Tjoa² \& Husain Marasabessy² \\ ${ }^{1}$ Mahasiswa Jurusan Kehutanan, Fakultas Pertanian, Universitas Pattimura, Ambon, 97233 \\ 2Jurusan Kehutanan, Fakultas Pertanian, Universitas Pattimura Ambon, 97233 \\ ${ }^{*}$ Email : ririn.haryanto@gmail.com
}

\begin{abstract}
The certainty of tenure rights has been a problem related to the use of forests by indigenous peoples. This study aims to identify indigenous peoples' existence and find out the forms of customary tenure rights in forest land management. The method used in this study is a qualitative method with a descriptive analysis to provide a true and accurate picture of the tenure rights of indigenous peoples. Research results show that indigenous peoples are still healthy with traditional institutions, and universal values are always maintained. The tenure system in Wakal is controlled by the State, control by the clan, and control by the individual family. There are forms of tenure rights in the three tenure systems that include ownership rights, tenure rights, exclusive voting rights, and proprietary use rights that are still actively applied in forest management.
\end{abstract}

KEYWORDS: Tenure Rights, Indigenous Peoples, Forest Management

\section{INTISARI}

Kepastian hak tenurial selama ini menjadi masalah terkait dengan pemnfaatan hutan oleh masyarakat adat. Penelitian ini bertujuan untuk mengidentifikasi keberadaan masyarakat adat dan mengetahui bentuk-bentuk hak tenurial masyarakat adat dalam pengelolaan lahan hutan. Metode yang digunakan dalam penelitian ini adalah metode kualitatif dengan analisis deskriptif untuk memberikan gambaran secara sistematik factual dan akurat mengenai hak-hak tenurial masyarakat adat. Hasil Penelitian menunjukan bahwa masyarakat adat masih tetap kuat dengan kelembagaan adat serta nilai-nilai adat yang tetap dipertahankan. Sistem tenurial yang terdapat di Negeri Wakal yaitu penguasaan oleh Negeri, Penguasaan oleh marga dan penguasaan oleh individu keluarga. Pada ketiga sistem tenurial tersebut terdapat bentuk hakhak tenurial yang mencangkup hak kepemilikan, hak garap, hak preferensi hak pilih ekslusif dan hak pemanfaatan yang masih kuat diterapkan dalam pengelolaan hutan.

KATA KUNCI : Hak Tenurial, Masyarakat Adat, Pengelolaan Hutan

\section{PENDAHULUAN}

Penetapan hutan adat dalam hutan Negara yang ditetapkan sebelumnya dalam UU 41 tahun 1999, telah mengalami perubahan dengan dikeluarkannya, Putusan Mahkamah Konstitusi No.35/PUU-X/2012 berisi beberapa pokok antara lain : Pertama, undangundang kehutanan yang selama ini memasukan hutan adat sebagai bagian dari hutan negara merupakan bentuk dari pengabaian terhadap hak-hak masyarakat adat dan merupakan pelanggaran konstitusi. Kedua, hutan adat dikeluarkan posisinya dari 

sebelumnya merupakan bagian dari hutan negara kemudian dimasukan sebagai bagian dari kategori hutan hak. Ketiga, pemegang hak atas tanah adalah pemegang hak atas hutan. Keempat, otoritas negara terhadap hutan negara dan hutan adat berbeda-beda. Kelima, hal pokok lainnya adalah penegasan bahwa masyarakat adat merupakan penyandang hak (Larson, 2013).

Pemanfaatan hutan oleh masyarakat adat mencakup berbagai klaim hak yang dapat disampaikan oleh masyarakat terhada lahan dan hasil hutan yang dikelola. Hal tersebut dapat menimbulkan konflik jika terdapat klaim yang tidak diatur dengan baik apabila terjadi klaim hak yang tumpang tindih pada satu objek yang sama. Kepastian hak-hak tenurial menjadi penting untuk pengelolaan hutan yang lestari.

Permasalahan land tenure masih mewarnai pengelolaan hutan di Indonesia sampai saat ini. Perencanaan dalam pembangunan kehutanan nampaknya perlu mengakomodir dengan baik keberadaan masyarakat di dalam kawasan hutan dengan kompleksitas keragamannya serta sistem tenurial yang ada di masyarakat, untuk memberikan jaminan kepastian tenurial (tenure security) bagi keberlangsungan pengelolaan sumber daya hutan. (Larson, 2013)

Permasalahan tenurial dan status kawasan hutan pada dasarnya merupakan dua elemen yang tidak dapat terpisahkan (Pruitt \& Rubin, 2009 ; Irawan $d k k ., 2016)$. Istilah tenurial mencakup substansi dan jaminan atas hak. Sebagai sumberdaya publik, hak tenurial terhadap hutan mencakup hak akses, hak pakai, hak eksklusif dan hak pengalihan. Ketidakpastian hak merupakan penyebab umum timbulnya konflik lahan (Herrera dan Passano, 2006).

Umumnya sistem penguasaan lahan hutan (forest land tenure) oleh masyarakat adat di Maluku memiliki 3 bentuk penguasaan lahan yaitu penguasaan oleh negeri, penguasaan oleh marga dan penguasaan oleh keluarga (Tjoa, 2017). Pada ketiga system penguasaan lahan tersebut digunakan untuk berkebun dan membuat dusung, guna memenuhi kebutuhan hidupnya. Sedangkan pemanfaatan hasil hutan mencakup hasil hutan kayu dan non kayu (Patta, 2012).

Ketidakpastian dalam penguasaan kawasan hutan dapat menghambat efektivitas pengelolaan hutan. Permasalahan ini dapat menimpa masyarakat lokal yang bermukim dan memanfaatkan lahan di dalam kawasan hutan, termasuk pihak luar yang mengakses lahan hutan tersebut (Handoyo, dkk. 2011) . Permasalahan Hak akses atas kawasan hutan terjadi akibat sistem perijinan yang kurang terpadu dan penguraian persoalan atas klaim lahan yang kurang memadai (Sylviani, 2014)

Di Provinsi Maluku, sampai saat ini dijumpai kesatuan-kesatuan masyarakat adat yang hidup didasarkan pada hukum adatnya dengan nama dan ukuran yang beragam. 

Melihat kesatuan masyarakat hukum adat sebagai suatu realitas, yang kepadanya diberikan pengakuan dan penghormatan sehingga eksistensinya tetap kuat. Hak sebagai suatu kesatuan masyarakat adat sebenarnya merupakan sesuatu yang ada dengan sendirinya dan tidak bergantung pada pengakuan dan penerapan yang ada di dalam hukum Negara, baik konstitusi maupun perundang-undangan (Titahelu, 2005 ; Mantuankotta, 2012).

Lebih lanjut Titahelu (2005) mengatakan bahwa isi atau content ini dapat ditentukan sejauh mana kesatuan masyarakat adat ini hendak diidentifikasi. Hal ini dapat dilakukan berdasarkan apa yang dinyatakan oleh mereka yang menyebut diri sebagai masyarakat hukum adat itu sendiri. Jadi, pernyataan dalam konstitusi saat ini adalah suatu pengukuhan terhadap kesatuan masyarakat hukum adat, sedangkan isi sesungguhnya dari apa yang disebut sebagai kesatuan masyarakat hukum adat adalah suatu realita (social reality) yang ditentukan oleh masyaraat hukum adat itu sendiri berdasarkan prinsip cultural self identification. Oleh karena itu proses memperoleh pengetahuan tentang kesatuan masyarakat hukum adat itu harus dapat diperoleh langsung dari kesatuan masyarakat yang menyatakan dirinya sebagai masyarakat hukum adat.

Negeri Wakal merupakan salah satu negeri adat yang memiliki aturan adat yang diterapkan dalam pengelolaan lahan hutan. Berbagai persoalan hak yang sering terjadi terkait dengan lahan terutama menyangkut batas lahan antar negeri membutuhkan adanya kepastian hak yang sesungguhnya terdapt di negeri tersebut. Kepastian hak dapat dijelaskan dengan identifikasi bentuk-bentuk hak apa saja yang dimiliki oleh masyarakat tersebut dengan keberadaan nilai dan norma serta aturan yang memperkuat kepastian hak atas lahan. Untuk itu penelitian ini dilaksanakan sebagai langkah awal menentukan kepastian hak atas lahan hutan dan diperkuat dengan eksistensi masyarakat adat.

\section{METODE PENELITIAN}

\section{Lokasi dan Waktu Penelitian}

Penelitian ini dilaksanakan di Negeri Wakal Kecamatan Leihitu Kabupaten Maluku Tengah (Gambar 1). Waktu Penelitian ini berlangsung pada Agustus 2019.

\section{Pengumpulan Data}

Sampel responden (KK) yang diwawancarai dipilih secara purposive dengan pertimbangan bahwa respoden memiliki lahan kelolah melalui aktifitas di hutan. Penelitian ini juga mewawancarai informan kunci. Sampel yang dipilih dilakukan secara purposive sampling dengan kriteria bahwa responden adalah tokoh-tokoh masyarakat yang mengetahui tentang kondisi masyarakat adat dan persoalan yang terkait dengan hak-hak tenurial masyarakat adat. Sampel yang dipilih dapat mencakup, Kepala Desa/Raja, Sekretaris Desa, Kepala Kewang, 

Hak Tenurial Masyarakat Adat Dalam Pengelolaan Hutan

(Haryanto Ririn $V^{*}$, Marthina Tjoa \& Husain Marasabessy)

Kepala Adat, Kepala Soa, dll. Jumlah responden yang dipilih sebanyak 30 orang yang mewakili masing-masing soa atau marga. Jumlah informan kunci yang dipilih sebanyak 5 orang yang terdiri dari pemerintah negeri dan tokoh adat.

Teknik pengumpulan data adalah cara-cara yang dilakukan peneliti untuk memperoleh data sesuai tujuan dari penelitian ini. Teknik pengumpulan data yang di lakukan dalam penelitian ini terdiri atas :

a) Teknik wawancara dengan responden KK dan responden informan kunci. Wawancara dilakukan dengan menggunakan kuesioner dan pertanyaan-pertanyaan yang diajukan bersifat terstruktur maupun terbuka, untuk mendapatkan penjelasan yang lebih kuat atas jawaban yang disampaikan oleh responden.

b) Teknik observasi dilakukan dengan cara melakukan pengamatan atas lahan yang dimiliki oleh masyarakat dan bentuk pengelolaan lahan. Selain itu juga dilakukan pengumpulan data dan dokumentasi dari pihak-pihak yang memiliki informasi tentang penelitian ini.

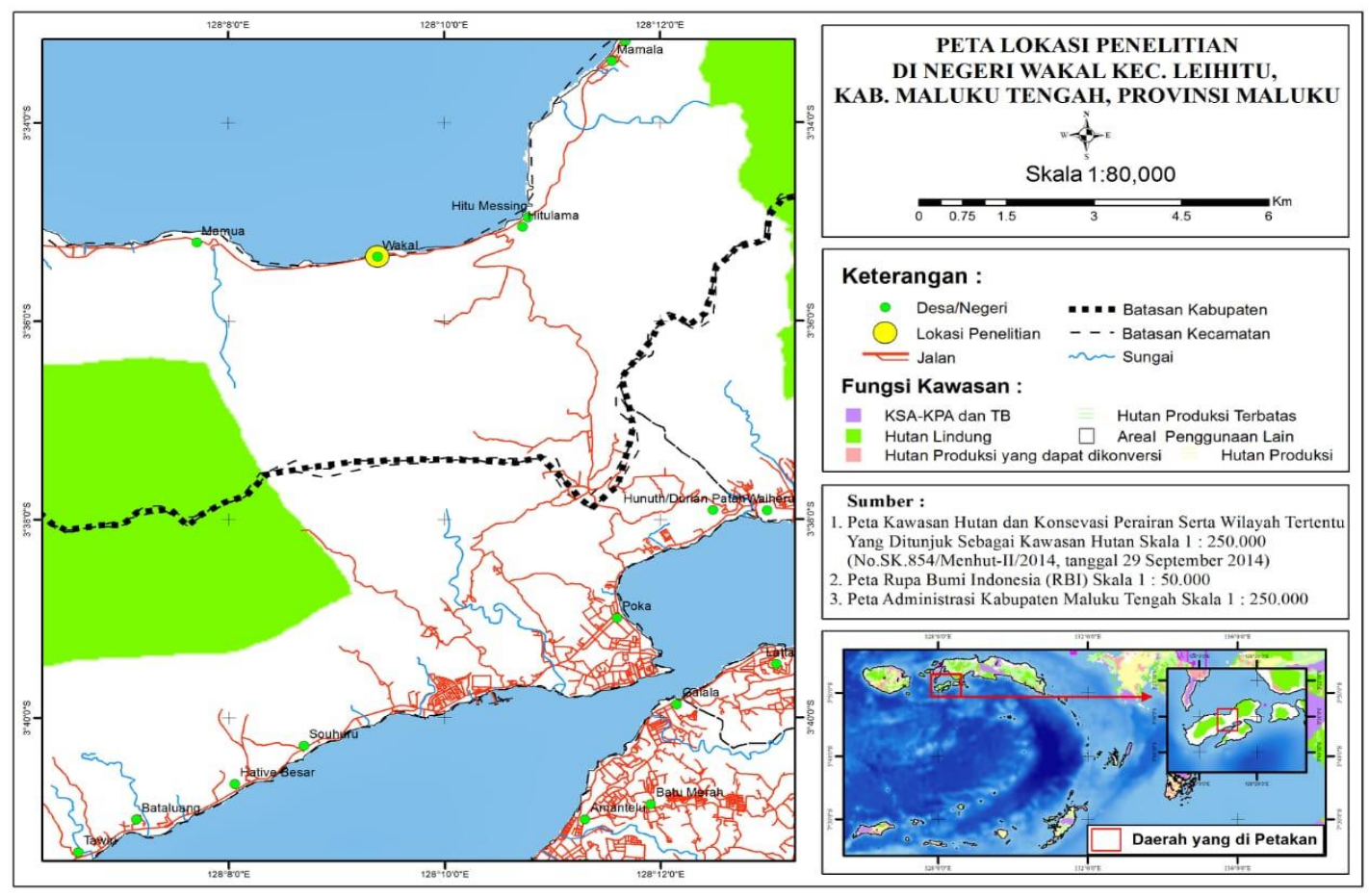

Gambar 1. Peta Lokasi Penelitian

\section{Analisis Data}

Analisis data dilakukan secara deskriptif kualitatif (Sugiyono, 2004) mencakup Identifikasi Eksistensi Masyarakat Adat, berdasarkan kriteria UUD No 41 tahun 1999, penjelasan Pasal 67. Analisis dimensi hak, berdasarkan mekanisme akses berbasis hak yang membedakan tipe-tipe hak atas lahan individu atau kelompok dan ha katas pepohonan (Ter Haar, 1960; Fortman, 1985; Lynch, 1993; Suharjito 1999). 


\section{HASIL DAN PEMBAHASAN}

\section{Sistem Tenurial Masyarakat adat dalam Pengelolaan Lahan.}

Hak tenurial yang terdapat pada masyarakat adat mencakup hak penguasaan lahan oleh negeri, hak peguasaan oleh kelompok marga dan hak penguasaan oleh individu (keluarga). Ketiga sistem tenurial tersebut memiliki aturan dan norma yang dibangun secara turun temurun. Hak pengusaan hasil hutan merupakan hak untuk memiliki, memanfaatkan dan mengelolah sumber daya hutan yang ada yang diperoleh secara turun-temurun dari nenek moyang dimana warisan kepada anak cucu mereka sampai sekarang, jadi mereka berhak atas tanah dan sumber daya hutan.

Hak atas tanah/lahan memiliki arti yaitu apabila tanah/lahan adalah milik individu, maka hutan atau lahan itu yang akan dikelola dan dimanfaatkan oleh individu sendiri. Hak penguasaan hasil hutan juga adalah hak untuk mengambil hasil hutan yang berada pada lahan yang dimiliki oleh keluarga/marga tertentu. Demikian juga untuk hak membuka lahan untuk berkebun atau membuat dusung, hak penguasaan sepenuhnya ada pada mereka namun tetap harus taat pada aturan-aturan yang ada dalam negeri.

\section{a) Penguasaan Lahan Negeri}

Hak penguasan oleh negeri dapat berupa ladang penggembalaan, kuburan yang berfungsi untuk memenuhi kebutuhan umum. System penguasaan oleh negeri mencakup pemanfaatan oleh seluruh anggota masyarakat asli yang terdapat di negeri Wakal. Bagi masyarakat luar yang ingin memanfaatkan lahan negeri harus mendapat ijin dari pemerintah negeri. Bentuk pemberian ijin biasanya dalam bentuk lisan yang langsung dikeluarkan dari mulut raja dan disaksikan oleh perangkat negeri.

Lahan milik negeri biasa dimanfaatkan oleh masyarakat hanya berupa usaha kebun, menanam tanaman umur panjang tetapi tidak menjadi hak milik warga atas lahan tersebut serta tidak dapat diperjualbelikan dan pindahtangankan.

Di dalam bentuk kepemilikan lahan dan hak atas penguasaannya tidak terdapat suatu kelembagaan negeri yang dapat mengatur tentang bentuk-bentuk hak tersebut sehingga tidak akan menutup kemungkinan apabila di kemudian hari terjadi konflik mengenai hak atas lahan tersebut, namun sampai sekarang konflik seperti itu belum pernah terjadi dan kalaupun sampai terjadi maka akan diselesaikan secara kekeluargaan.

Status kepemilikan, hak akses dan penguasaan lahan di Desa Wakal, mayoritas masyarakat lahir di wakal umumnya memiliki lahan. Masyarakat Negeri Wakal 90\% memiliki lahan yang ada di sekitar kawasan hutan dan sisanya berada di sekitar pemukiman. Lahan yang dimiliki tidak pernah berkonflik dengan marga lain dan juga lahan yang mereka miliki umumnya tidak dibeli tetapi warisan turun temurun. Sekitar $80 \%$ lahan yang dimiliki adalah 
warisan dari orang tua mereka, dan sisanya lahan yang sekarang dimiliki diperoleh dengan mengusahakan lahan kosong yang tidak ada pemiliknya dan lahan tersebut ditanamai dengan tanaman sehingga secara langsung lahan tersebut menjadi milik orang yang mengelolanya.

Masyarakat Negeri Wakal memiliki hak atas lahan dan memungut sumberdaya alam yang ada di atasnya. Pendatang yang memanfaatkan sumberdaya alam di negeri wakal diperoleh setelah mendapat ijin dari pemerintah negeri Wakal.

\section{b) Penguasaan Lahan Marga}

Penguasaan oleh marga mencakup penguasaan bersama anggota marga untuk memanfaatkan baik lahan maupun hasil hutan (tumbuhan) yang ada dalam lahan tersebut. Setiap marga pemilik lahan yang memanfaatkan hasil lahan dapat berupa pemanfaatan buah-buahan, sayuran dan obat-obatan. Pemanfaatan oleh marga bersifat sementara dan biasanya berlaku bagi setiap anggota marga. Bersifat sementara karena dalam memanfaatkan tumbuhan/ pohon tidak tetap pada satu pohon saja biasanya bisa berpindah atau sesuai dengan kebutuhan anggota marga tersebut. Sistem penguasaan oleh marga hanya terdapat hak pakai terhadap hasil lahan tidak berlaku hak milik atas lahan tersebut. Sehingga tidak ada system pengalihan lahan pada pihak lain. Bagi masyarakat diluar marga pemilik lahan bila ingin memanfaatkan lahan tersebut maka perlu mendapat ijin dari ketua marga setelah mendapat persetujuan dari seluruh anggota marga.

Pemanfaatan lahan umumnya untuk menanam tanaman umur panjang, berkebun, Hak kepemilikan lahan milik marga memang hak sepenuhnya milik marga, dimana dalam pemanfaatannya masing-masing orang dari marga mendapatkan bagiannya tetapi tanah tersebut tetap menjadi lahan milik marga (Hak Dati), anggota marga diberikan hak untuk memanfaatkan saja tetapi tidak dapat memiliki hak pribadi atas tanah apalagi sampai diperjualbelikan atau dipindahtangankan, kecuali ada yang berniat membangun rumah maka akan diberikan sebidang tanah.

\section{c) Penguasaan Lahan Keluarga}

Penguasaan lahan individu (keluarga) merupakan lahan pemberian marga bagi setiap keluarga untuk dimanfaatkan dengan menanam tanaman umur panjang dan hasil tanaman tersebut menjadi milik keluarga tersebut. Anggota marga lain tidak berhak atas lahan yang sudah diusahakan. Dikemudian hari apabila hak keluarga sudah diberikan dan selanjutnya tidak dimanfaatkan lagi, maka lahan tersebut dapat diambil lagi menjadi milik marga dan dapat dimanfaatkan oleh anggota marga lain. Penguasaan lahan keluarga dapat dialihkan kepada orang lain dalam bentuk diwariskan ataupun dijual. Biasanya ada peluang untuk pembuatan sertifikat milik. Namun saat ini sertfikat hanya berlaku pada lahan perumahan. 

Kepemilikan lahan milik pribadi merupakan hak perorangan yang diperoleh dari warisan orang tua dan usaha mereka sendiri, namun ada juga yang memiliki tanah dari hasil pemberian marga lain atau marga asli (Marga Paila, Lewaru, dan Patta) dan itu akan menjadi hak milik pribadi orang tersebut, baik untuk dimanfaatkan sebagai bercocok tanam maupun untuk membangun rumah. Akan tetapi lahan tersebut tidak dapat diperjuabelikan namun dapat dipindahtangankan, dapat mengeluarkan pihak yang tidak berhak serta dapat menegakkan hak-haknya.

\section{Jenis-Jenis Hak Tenurial}

\section{a) Hak kepemilikan}

Kepemilikan lahan pada negeri Wakal, khususnya kepemilikan pribadi (perorangan) terjadi melalui pengakuan oleh pemerintah negeri dan masyarakat Negeri Wakal. Tanda kepemilikan biasanya secara alami berupa jenis tanaman yang sudah diusahakan oleh pemilik pada lahan yang sudah diberikan ijin oleh negeri maupun marga. Pemberian menjadi hak milik berlaku jika lahan yang akan dikelola oleh keluarga sebelumnya tidak ada pemiliknya secara individu, masih berupa kepemlikan secara marga atau negeri. Jika kepemilikan lahan oleh individu lain dan lahan tersebut kosong, maka kepemilikan berdasarkan pengakuan pemberiann oleh indvidu tersebut. Pemberian hak kepemilikan berlaku hak warisan kepemilikan turun temurun untuk dimanfaatkan oleh anggota keluarga yang telah diberikan hak kepemilikannya. Berlaku kepemilikan hanya pada tumbuhan yang diusahakan oleh keluarga sedangkan kepemilikan atas lahan tidak berlaku, status lahan hanya pinjam pakai dan tidak boleh ada proses jual beli lahan.

\section{b) Hak garap}

Hak garap adalah hak yang dimilki oleh seseorang untuk mengusahakan tanah atau lahan untuk menanam berbagai jenis tanaman. Tanaam yang diusahakan adalah tanaman yang habis sekali panen dapat diperbaharui kembali. Tanaman yang bisa diperbaharui kembali adalah sayur-sayuran, pisang, pepaya, cili, tomat dll pada lahan kebun.

Berdasarkan hasil penelitian diperoleh bahwa masyarakat Negeri Wakal 100\% setelah selesai panen lahan yang mereka miliki dapat digarap kembali. Hak garap berlaku selama orang tersebut diberikan ijin oleh pemilik. Berlaku juga bahwa hak garap diperoleh dengan menyewa lahan tersebut dan hasil dari garapan itu berupa tanaman dibagi dua dengan pemilik lahan.

\section{c) Hak Preferensi}

Pemegang mempunyai hak untuk menanam di masa datang, misalnya dengan memberi tanda pada sebidang lahan. Hak ini berlaku pada lahan kebun dan dusung. Masyarakat memiliki kebiasaan menanam tanaman umur panjang bersama dengan tanaman 

pangan sehingga pada saat panen, lahan tersebut dapat dimanfaatkan pada masa yang akan datang dengan memanfaatkan tanaman umur panjang tersebut. Hak preferensi bisa dimanfaatkan seterusnya karena menjadi hak milik warga, kecuali bila lahan tersebut dijual. Hak preferensi ditandai dengan pohon durian, pohon titi. Pohon inijarang jadi dapatdigunakan. Ada kelompok yang memanfaatkan lahan kerabat, sehingga akses juga berlaku bagi masyarakat yang bukan pemilik lahan.

Pemanfaatan lahan hutan berhak dimiliki masyarakat karena tanah di hutan dimiliki oleh masing-masing mata rumah yang diturunkan dari leluhur. Pemanfaatan lahan bisa dikeluarkan jika orang tersebut bikin onar.

\section{d) Hak Pilih ekslusif}

Hak pilih ekslusif menyangkut hak seseorang untuk membeli sebidang tanah seharga yang ditawarkan pembeli lain yang prospektif. Hak ini tidak terdapat pada masyarakat adat negeri Wakal karena berlaku tidak jual beli tanah yang dimiliki oleh marga maupun individu. System yang berlaku yaitu bahwa pemilik lahan memberikan pinjam lahan kepada mereka yang ingin mengusahakan lahan milik. Berlaku aturan bagi lahan yang dipinjam untuk usaha kebun hasilnya dibagi (70:30) dengan pemilik lahan tersebut. Dengan demikian kepemilikan lahan tetap tidak berpindah tangan.

\section{e) Hak Pemanfaatan}

Lahan yang dipegang oleh individu sebagai bagian dari anggota kelompok marga memiliki hak pemilikan. Pemanfaatan hasil hutan bertujuan untuk pemenuhan kehidupan sehari-hari dan juga dapat dijual. Masyarakat menganggap lahan merupakan modal untuk berproduksi. Lahan yang dimiliki masyarakat Negeri Wakal dapat dilakukan penanaman dan pemanfaatannya.

Hak pemanfaatn atas lahan hutan bukan sebatas pada lahan untuk kebun dan dusung, tetapi juga pemanfaatan pohon atau tumbuhan yang terdapat di atas lahan tersebut. (Fortman, 1985). Pemanfaatan pohon dan tumbuhan biasanya berdasarkan penguasaan atas lahan dimana pohon atau tumbuhan yang tumbuh. Namun pemanfaatan pohon juga berlaku bagi mereka yang tidak termasuk dalam pemilikan lahan tetapi diberikan ijin untuk pemanfaatan hasil hutan tersebut. Hal tersebut menunjukan bahwa walaupun tidak memiliki hak milik lebih penting adalah memiliki hak untuk memanfaatkan walaupun kebanyakan hanya bersifat subsisten. Pemanfaatan pohon atau tumbuhan untuk dijual biasanya berlaku bagi mereka yang memiliki hak milik keluarga atau individu.

\section{Hak Ulayat}

Tanah ulayat sebagai tanah bersama pada warga masyarakat hukum adat yang bersangkutan. Tanah ulayat masyarakat adat merupakan bentuk wilaya hukum masyarakat 

adat yang kepemilikannya dikuasai secara kemunal oleh sekelompok masyarakat yang mendiami wilaya tertentu dengan pimpinan oleh seorang tokoh adat.

lahan ulayat yang dimiliki Masyarakat Negeri Wakal dapat mengeluarkan orang atau pihak-pihak yang tidak berkepentingan dengan lahan tersebut, sedangkan lahan ulayat yang dimiliki oleh masyarakat Negeri Wakal tidak dapat digunakan secara bebas oleh anggota marga dan masyarakat yang ada. lahan ulayat yang sekarang mereka miliki dapat digunakan oleh pihak luar/lain setelah mendapat ijin dari pemilik lahan ulayat, sedangkan $100 \%$ masyarakat lahan ulayat yang mereka miliki sekarang yang dapat digunakan oleh pihak luar, ketika ada pelanggaran diwajibkan membayar ganti rugi atau menanggung biaya, masyarakat negeri wakal 100\% lahan petuanan yang mereka miliki tidak pernah dapat di allihkan kepada pihak lain.

Masyarakat negeri Wakal 100\% akan terus memiliki hak akses lahan dan sumberdaya hutan yang ada, begitu pula dengan hak kepemilikan yang mereka miliki tidak pernah ada konfik dengan marga lain, dan masyarakat negeri wakal 100\% memahami aturan pengelolaan hutan secara tradisional atau adat dalam penggunaan dan pengelolaan sumberdaya hutan. Sedangkan masyarakat negeri wakal 57\% tidak pernah ada aturan yang secara tradisional/adat yang mengatur tentang penggunaan dan pengelolaan sumberdaya hutan, dan $43 \%$ yang mengatakan bahwa sumberdaya hutan yang ada dapat dikelola secara tradisional/adat.

Berdasarkan hak kepemilikan lahan secara adat, hutan yang ada di Negeri Wakal adalah milik petuanan negeri/tanah adat sehingga untuk pemanfaatan dan pengelolaan lahan tersebut oleh masyarakat harus melalui ijin. Lahan tersebut dapat dimanfaatkan dan hasilnya dibagi dengan negeri apabila ada kesepakatan dari keduanya.

Menurut masyarakat Negeri Wakal, mereka beranggapan bahwa hak atas tanah adalah hak milik atau kepunyaan masyarakat terhadap tanah-tanah serta hasil sumber daya alam atau hutan yang ada di sekitar negeri (petuanan) yang dimiliki secara adat. Mengenai hak atas tanah pada negeri wakal ada yang mendapatkan hak atas lahan dari orang tua dan pembagian dari tanah/lahan marga dimana diadakan rapat dati (Rumah Tua) kemudian dalam rapat tersebut akan ada pembagian kepada masing-masing kepada keluarga dan tanah/lahan yang telah sepenunya menjadi haknya.

Hak ulayat dimanfaatkan oleh dusun lain di luar Wakal, tetapi sudah mendapat ijin. Pernah ada yang memanfaatkan lahan tanpa ijin oleh masyarakat pemilik lahan diusir, walaupun sudah ditanam dengan jenis tanaman. Hutan adat di Wakal dimanfaatkan oleh anak adat negeri Wakal. Hutan adat adalah hutan yang dikelola masyarakat untuk keperluan bersama. 


\section{KESIMPULAN}

Keberadaan masyarakat adat di Negeri Wakal ditunjukan dengan adanya pemenuhan kriteria masyarakat adat dalam UU 41 1999, mencakup kehidupan masyarakat yang masih tetap dalam bentuk paguyuban berdasarkan hubungan kekerabatan yang masih terjaga. Peran dan fungsi kelembagaan adat masih tetap berjalan walaupun beberapa fungsi ada yang telah berubah. Wilayah hukum adat masih bersifat alamiah namun mendapat pengakuan dari kelembagaan adat yang ada. Pranata dan Hukum adat tetap berlaku berdasarkan kearifan local yang telah berkembang sejak leluhur. Pemanfaatan lahan dan hasil hutan merupakan bagian dari masyarakat adat untuk memenuhi kebutuhan hidup setiap hari.

Sistem tenurial yang terdapat di Negeri Wakal yaitu penguasaan oleh Negeri, penguasan oleh marga dan penguasaan oleh individu keluarga. Pada ketiga system tenurial tersebut terdapat bentuk Hak-hak tenurial mencakup hak kepemilikan, hak garap, hak preferensi, hak pilih ekslusif dan hak pemanfaatan. Hak ulayat dapat mencakup seluruh hak yang terdapat pada system tenurial yang ada. Hak atas pohon dapat dibedakan dari hak atas lahan karena terdapat kepemilikan hak atas pohon tetapi tidak memiliki hak atas lahan.

\section{DAFTAR PUSTAKA}

Fortmann L 1985 The tree tenure factor in agroforestry with particular reference to Africa. Agroforestry Systems 2: 229-251.

Handoyo, Suka P, A \& Ginoga, I, A. 2011. Identifikasi Tenurial Sebagai Pra-Kondisi Untuk Implementasi REE+. Jurnal Sosial Dan Ekonomu Hutan Vol. 8 No. 4. Hal 306-320.

Herrera, A., dan M.G. da Passano. (2006). Land Tenure Alternative Conflict Management. Rome: Food and Agriculture Organization of the United Nations (FAO).

Irawan A., Mairi. K. \& Ekawati S. 2016. Analisis Konflik Tenurial Di Kesatuan Pengelolaan Hutan Produksi (KPHP) Modal Poigar. Jurnal Wasian Volume 3 Nomor 2.

Larson, A.M. 2013. Hak Tenurial Dan Akses Ke Hutan: Manual Penelitian Untuk Peneliti. CIFOR, Bogor, Indonesia. 75 P.

Lynch O.J. 1993. Securing community based tenurial rights in the tropical forest in Asia: An overview of current and prospective strategies Policy and legislation in community forestry. Editor: Warner K, et al. Bangkok, Proceeding of a workshop RECOFT

Mantuankotta. K. J. 2012. Eksistensis Masyarakat Hukum Adat Dalam Mempertahankan Sumber Daya Alam. Jurnal Sasi, Fakultas Hukum Unpatti.

Patta, L. 2012. Status Kepemilikan Lahan dan Hak atas Penguasaan Hasil Hutan oleh Maysarakat Adat di Negeri Wakal. [Skripsi] Universitas Pattimura. Ambon.

Pruitt, Dean G dan Jeffrey Z. Rubin. 2009. Teori Konflik Sosial. Pustaka Pelajar: Yogyakarta

Sugiyono. 2014. Memahami Penelitian Kualitatif. Alvabeta, Cv. Bandung. 234 p.

Suharjito D. 1999. Hak-Hak penguasaan atas hutan di Indonesia. Program Penelitian dan Pengembangan Kehutanan Masyarakat (P3KM). Fakultas Kehutanan IPB. 
MAKILA:Jurnal Penelitian Kehutanan Volume 13, Nomor 2 (139-149)

Susilowati. 2015. Konflik Tenurial Dan Sengketa tanah Kawasan Hutan Yang Di Kelola Oleh Perum Perhutani jurnal repertorium ISSN 2355-2646

Sylviani. \& Ismantul H. 2014. Analisis Tenurial Dalam Pengembangan Kesatuan Pengelolaan Hutan (KPH). Studi Kasus KPH Gedong Wani Provinsi Lampung. Vol 11 No.4 Hal 309-322

Ter Haar Bzn B. 1960. Azas-asaz dan Susunan hukum Adat, PT. Pradnya Paramita. Jakarta.

Titahelu,R.Z, 2005, Hukum Adat Maluku Dalam Konteks Pluralisme Hukum, Implikasi Terhadap Managemen Sumber Daya Alam Maluku, disampaikan pada pengresmian penerimaan Jabatan Guru BesarDalam Bidang Ilmu Hukum, Pada Fakultas Hukum Universitas Pattimura, Ambon

Tjoa, M. 2017. Penguatan Sistem Penguasaan Lahan Hutan pada Masyarakat Adat di Kabupaten Seram Bagian Barat, Maluku. [Disertasi] Institut Pertanian Bogor. 